\title{
ANALISIS STRATEGI PEMASARAN DALAM RANGKA MENINGKATKAN KUALITAS PELAYANAN TERHADAP JAMAAH UMROH PADA PT. DAANISH MIKA SALSA DI BANDAR LAMPUNG
}

\author{
Iwan Zulfikar ${ }^{(1)}$, Andika Palewa ${ }^{(2)}$ \\ Fakultas Ekonomi Universitas Sang Bumi Ruwa Jurai \\ iwan.zulfikar@fe.saburai.ac.id, andikapalewa01@gmail.com
}

\begin{abstract}
Abstrak.Saat ini, semakin banyak pesaing dalam hal biro perjalanan dan semakin banyak pula biro-biro yang menawarkan berbagai fasilitas pelayanan yang disediakan, para calon jamaah haji dan umroh bisa memilahmilah biro mana yang terbaik dalam pelayanannya. Sebagai salah satu biro perjalanan ibadah umroh, PT. Daanish Mika Salsa dituntut untuk memberikan pelayanan dengan kualitas terbaik, sehingga diperlukan strategi-strategi guna meningkatkan pelayanan kepada jamaah. Tujuanpenelitian ini adalah untuk mengetahui bagaimana proses pelayanan terhadap jamaah umroh di PT. Daanish Mika Salsa, untuk mengetahui strategi apa saja yang dilakukan oleh PT. Daanish Mika Salsa dalam meningkatkan kualitas pelayanan terhadap jamaah umroh, dan untuk mengetahui strategi apakah yang paling efektif yang dilakukan PT. Daanish Mika Salsa dalam meningkatkan kualitas pelayanan terhadap jamaah umroh. Metode penelitian yang digunakan di dalam penelitian ini adalah metode analisis data secara kualitatif, yaitu dengan menafsirkan, menginterprestasikan, dan mengklasifikasikan dengan menggunakan kerangka teori dan kerangka konsep yang bersumber dari data primer yaitu wawancara maupun data sekunder yaitu jumlah jamaah umroh, menggunakan teknik pengumpulan data studi kepustakaan dan studi lapangan seperti observasi, interview dan dokumentasi. Hasil dari penelitian ini adalah PT. Daanish Mika Salsa melakukan segala sesuatunya sesuai dengan prosedur yang telah ditetapkan oleh perusahaan guna meningkatkan pelayanan kepada jamaah.Strategi yang dilakukan dalam meningkatkan kualitas pelayanan adalah dengan menggunakan strategi Product (Produk), Price (Harga), Place (Tempat), Promotion (Promosi), serta kerja sama dengan travel lain yang sejenis. Strategi yang dilakukan tidak semata untuk meraih keuntungan, tetapi juga sebagai sarana dalam peningkatan kulaitas pelayanan kepada jamaah.Strategi yang paling efektif dilakukan adalah strategi promosi, karena terbukti mampu menaikkan jumlah jamaah melebihi target dibandingkan tahuntahun sebelumnya.
\end{abstract}

Kata kunci: Strategi Pemasaran, Peningkatan Kualitas Pelayanan, Umroh.

\section{PENDAHULUAN}

Antusiasme masyarakat terhadap ibadah umroh yang dianggap sebagai penggantiibadah haji, membuat para pengusaha berlomba-lomba untuk membuat biro perjalanan religi ini. Saat ini terdapat banyak agen perjalanan yang menawarkan beberapa paket perjalanan ibadah umroh, mulai dari harga yang paling ekonomis, sampai dengan harga yang cukup tinggi. Tentunya ada perbedaan diantara harga yang ditawarkan dengan fasilitas yang didapat oleh para jamaah. Bahkan, ada beberapa biro perjalanan yang bekerja sama dengan beberapa bank tertentu yang menyediakan fasilitas keberangkatan dengan membayar secara mencicil, sehingga masyarakat yang ingin melaksanakan ibadah umroh, namun belum memiliki cukup uang, dapat tetap berangkat melaksanakan ibadah umroh tersebut, biayanya bisa dicicil dengan cara mengangsur setiap bulan melalui bank yang 
bersangkutan. Kepraktisan inilah yang menjadi salah satu strategi dari agen atau biro pejalanan tersebut.

Pada dasarnya, kegiatan ibadah umroh tidak hanya dilihat berdasarkan kepraktisan dan keekonomisannya saja, tetapi juga harus diperhatikan dalam pelaksanaannya, yaitu standar pelayanan saat masih di tanah air dan di Makkah, standar pelayanan di tanah air banyak aspek penting yang harus diperhatikan pembinaannya seperti dalam pelayanan jasa (pembayaran setoran ongkos umroh ke bank, pengurusan dokumen umroh, pemeriksaan kesehatan calon jamaah), penyediaan perlengkapan, dankonsultasi keagamaan. Sedangkan setandar pelayanan ibadah umroh di tanah suci adalah pelayanan akomodasi, transportasi, konsumsi, kesehatan, serta bimbingan ibadah umroh.

Undang-Undang

Indonesia No 13 tahun 2008 tentang Penyelenggaraan Haji dan Umroh dijelaskan tentang hal-hal yang perlu diperhatikan di dalam penyelenggaraan perjalanan ibadah haji dan umroh, yakni pembinaan, pelayanan dan perlindungan dengan menyediakan pelayanan administratif, bimbingan manasik haji, akomodasi, transportasi, pelayanan kesehatan, keamanan dan hal-hal yang di perlukan oleh jemaah haji dan umroh.

Setiap pelaksanaan pelayanan ibadah umroh haruslah dilaksanakan secara maksimal dan profesional untuk menghindari setiap permasalahan yang dihadapi.

Jika tanpa strategi yang baik, maka pelayanan yang akan didapat para jamaah umroh tidak akan memuaskan. Kompleksitas permasalahan dalam penyelenggaraan umroh dari tahun ketahun, menuntut lahirnya suatu strategi yang memicu agar kegiatan pelayanan dapat menjadikan suatu kajian dalam memberi kepuasan kepada para konsumen atau jamaah yang meliputi Kehandalan, Responsif, Keyakinan, Empati, dan Berwujud.Sehingga apa yang di berikan dapat dipersepsikan baik atau lebih dan akan dijadikan sebagai tempat pemberi pelayanan jasa di bidang umroh di tahun berikutnya. Strategi di dalam kualitas pelayanan khususnya dibidang jasa merupakan salah satu bentuk upaya dalam memberikan tingkat kepuasan kepada konsumen dengan tingkat keunggulan dari apa yang dimiliki oleh penyedia jasa yang diharapkan agar keunggulan tersebut menjadi prioritas utama dalam memuaskan harapan konsumen.

Maraknya pemberitaan di media mengenai kasus penipuan yang dilakukan oleh beberapa biro perjalanan haji dan umroh, turut mempengaruhi kualitas pemberian pelayanan dan perlindunganpada jamaah. Jamaah tidak lagi merasa nyaman dalam memilih biro perjalanan, karena adanya rasa takut tidak diberangkatkan. Hal ini berpengaruh pada biro perjalanan lain yang secara murni melakukan penyelenggaraan perjalanan ibadah umroh tanpa adanya unsur penipuan, dan secara tidak langsung menurunkan target pencapaian.

Agar tujuan pelaksanaan ibadah umroh selalu sukses dan mencapai target yang ingin dicapai, maka perlu adanya strategi dibidang pelayanan. Sehingga apa yang menjadi cita-cita jamaah dalam menunaikan ibadah umroh ini bisa di peroleh secara sempurna dan memuaskan.

PT. Daanish Mika Salsa (DMS) merupakan salah satu biro perjalanan yang menyelenggarakan perjalanan ibadah umroh. Biro perjalanan ini sudah berdiri sejak tahun 2009, namun sebelumnya masih menginduk kepada kantor pusat, yang berada di Jakarta. Dalam setahun, PT. Daanish Mika Salsa bisa memberangkatkan sampai dengan seribu jamaah, ditambah lagi, sudah tiga tahun berturut-turut dipercaya sebagai penyelenggara perjalanan 
ibadah umroh yang diadakan oleh Pemerintah Kota Bandar Lampung. Hal ini membuat masyarakatsemakin yakin dan tertarik, sehingga mempercayakan perjalanan ibadah umroh mereka kepada PT.Daanish Mika Salsa.

Berdasarkan latar belakang di atas, maka penulis tertarik melakukan penelitian dengan judul :“Analisis Strategi

Pemasaran Dalam

MeningkatkanKualitas

Terhadap Jamaah Umroh Pada PT. Daanish Mika Salsadi Bandar Lampung".

\section{KAJIAN TEORI}

\section{Pengertian Strategi}

Strategi adalah pendekatan
berkaitan denganpelaksanaan gagasan, perencanaan, dan eksekusi sebuah aktivitas dalam kurunwaktu tertentu. Didalam strategi yang baik terdapat koordinasi tim kerja,memiliki tema, mengidentifikasi faktor pendukung yang sesuai dengan prinsipprinsip pelaksanaan gagasan secara rasional, efisien dalam pendanaan, danmemiliki taktik untuk mencapai tujuan secara efektif.

Kata strategi berasal dari bahasa Yunani kuno "stratogos" yang berarti seniberperang. Pada dasarnya, kata stratogos tersebut diartikan sebagai sesuatuyang dilakukan oleh para jendral dalam membuat rencana untuk menakhlukanmusuh dan memenangkanpeperangan.

Menurut Haripurwo

(2001:20), suatustrategi memiliki dasar-dasar atau skema untuk mencapai sasaran yang dituju,jadi dapat disimpulkan bahwa strategi merupakan alat untuk mencapai suatutujuan.
Departemen Pendidikan dan Kebudayaan Republik Indonesia (1997:199) didalam Kamus Besar Bahasa Indonesia (KBBI) mengartikan istilah strategisebagai suatu seni atau ilmu yang menggunakan sumber daya untukmelaksanakan kegiatan tertentu. Jadi, dapat disimpulkan bahwa, strategimerupakan suatu cara yang digunakan dalam melakukan pekerjaan tertentu,agar dapat mencapai sesuatu sesuai dengan apa yang telah direncanakan.

\section{Pengertian Manajemen Strategi}

Menurut Siagian (2002:31), manajemen strategi ialah suatu tindakan dankeputusan yang bisa dipergunakan untuk memformulasikan dan jugamengimplementasikan strategi yang mempunyai daya saing yang tinggi dansesuai dengan perusahaan ataupunlingkungan agar mencapai target maupunsasaran dari organisasi.

Pengertian lain dari manajemen strategi ialah suatu disiplin ilmu yang menyusun,menerapkan, dan mengevaluasi sebuah keputusan fungsional yang dapatmemungkinkan suatu perusahaan mencapai tujuannya. Merupakan suaturangkaian kegiatan-kegiatan pengambilan keputusan yang bersifat mendasar danmenyeluruh, disertai dengan penetapan dan cara melaksanakannya yang telahdibuat oleh pimpinan lalu diterapkan oleh seluruh jajaran yang ada dalam suatuorganisasi atau perusahaan untuk mencapai targetnya. Untuk mencapai tujuanorganisasi, manajemen strategi mengkombinasikan segala macam bentuk aktivitasyang berasal dari bagian funsional suatu bisnis.

\section{Pengertian Kualitas}

Kualitas adalah tujuan yang sulit dipahami (tujuan yang sulit 
dipahami),karena harapan para konsumen akan selalu berubah. Setiap standar baru ditemukan, maka konsumen akan menuntut lebih untuk mendapatkan standar baru lain yang lebih baru dan lebih baik.

Menurut Wahyu (2003:8), dalam quality vocabulary, kualitas didefinisikan sebagi totalitas dari karakteristik suatu produk yang menunjang kemampuannya untuk memuaskan kebutuhan yang dispesifikasikan atau ditetapkan. Kualitas seringkali diartikan sebagai kepuasan pelanggan (customer satisfaction) atau kesesuaian terhadap kebutuhan atau persyaratan (conformance to the requirements).

\section{Pengertian Pelayanan}

Pelayanan dalam hal ini sangat erat kaitannya dengan hal pemberian kepuasaan terhadap pelanggan, pelayanan dengan mutu yang baik dapat memberikan kepuasaan yang baik pula bagi pelanggannya, sehingga pelanggan dapat lebih merasa diperhatikan akan keberadaanya oleh pihak perusahaan.

Menurut Kasmir (2005:26), pelayanan diartikan sebagai tindakan atau perbuatan seseorang atau organisasi untuk memberikan kepuasan kepada pelanggan atau nasabah. Sedangkan pendapat lain pelayanan di berikan sebagai tindakan atau perbuatan seseorang atau organisasi untuk memberkan kepuasan kepada pelanggan atau nasabah. Tindakan tersebut dapat dilakukan melalui cara langsung melayani pelanggan. Artinya karyawan langsung berhadapan dengan pelanggan atau menempatkan sesuatu dimana pelanggan sudah tahu tempatnya atau pelayanan melalui telepon.

Jadi, dapat disimpulkan bahwa pelayanan merupakan suatu proses keseluruhan dari pembentukan citra perusahaan, baik melalui media berita, membentuk budaya perusahaan secara internal, maupun melakukan komunikasi tentang pandangan perusahaan kepada para pemimpin pemerintahan serta publik lainnya yang berkepentingan.

\section{Strategi Pemasaran}

Menurut Hani Handoko (2000: 4), strategi pemasaran merupakan strategiuntuk melayani pasar atau segmen pasar yang di jadikan target oleh perusahaan. Definisi strategi pemasaran adalah, logika pemasaran yang digunakan oleh perusahaan dengan harapan agar unit bisnis dapat mencapai tujuan perusahaan. Merancang strategi pemasaran yang kompetitif dimulai dengan melakukan analisis terhadap pesaing.

Ditambahkan oleh Handoko (2000: 6), dalam melaksanakan kegiatan pemasaran, perusahaan mengkombinasikan empat variabel yang sangat mendukung didalam menentukan strategi pemasaran, kombinasi keempat variabel itu dikenal dengan istilah bauran pemasaran (marketing mix) yang terdiri dari produk (product), harga (price), tempat (place) dan promosi (promotion).

\section{Standar Pelayanan Pada Biro Perjalanan Umroh}

Menurut Sukayat (2016:132), ruang lingkup manajemen pelayanan umrahsebagaimana diatur oleh undangundang Repubik Indonesia, meliputi pelayanan, pembinaan, dan perlindungan. (Tata Sukayat, Manajemen Haji Umroh dan Wisata Agama, PT Remaja Rosda Karya, Bandung, 2016, hlm. 132).

a. Pelayanan

1) Administrasi

2) Bimbingan Manasik

3) Transportasi

4) Akomodasi

5) Konsumsi 
6) Kesehatan

7) Pembinaan

8) Perlindungan

\section{METODE PENELITIAN}

\section{Objek Penelitian}

Objek Penelitian dalam penelitian ini adalah PT. Daanish Mika Salsa (DMS) Bandar Lampung. Penelitian dilaksanakan pada rentang waktu bulan April sampai bulan Juni 2018.

\section{Metode dan Teknik Pengumpulan Data}

Sumber data di dalam penelitian ini yaitu :

1. Data Primer yaitu data yang dikumpulkan dan diolah sendiri oleh penelitilangsung dari responden. Dalam penelitian ini data primer diperoleh dengan cara wawancara kepada Managerdan Marketing PT. Daanish Mika Salsa. Wawancara di dalam penelitian ini meliputi strategi yang digunakan oleh PT. Daanish Mika Salsa dalam rangka meningkatkan pelayanan kepada jamaah, faktor-faktor pendukung strategi, kendala-kendala yang dihadapi, serta kompetitorkompetitor yang menjalankan usaha sejenis.

2. Data Sekunder yaitu data yang diperoleh dari pihak lain yang telah mengolah atau mempublikasikan data primer seperti diperoleh dari Laporan Tahunan, Majalah Ilmiah, Buletin, dan sebagainya. Dalam hal ini, yang menjadi data sekunder adalah data jamaah umroh pertahun.

Langkah-langkah pengumpulan data yang penulis lakukan dengan mengadakan penelitian lapangan yaituPenelitian yang dilakukan padaPT. Daanish Mika Salsa
(DMS),adapun teknik yang digunakan dalam pengumpulan data adalah dengan :

1. Observasi

2. Interview atau wawancara

3. Dokumentasi

\section{Metode Analisis Data}

Penelitian ini analisis data dilakukan secara kualitatif, yaitu dengan caramenafsirkan, menginterprestasikan, dan mengklasifikasikan dengan menggunakankerangka teori dan kerangka konsep yang hasilnya diuraikan dan dijelaskan kedalam bentuk kalimat yang jelas, teratur, logis dan efektif sehingga diperoleh gambaran yang jelas, tepat, dan dapat ditarik kesimpulan sehingga dari beberapa kesimpulan tersebut dapat diajukan saran-saran.

\section{HASIL DAN PEMBAHASAN}

Berdasarkan hasil wawancara dan analisis yang penulis lakukan, penulis dapat menarik suatu jawaban bahwa sejauh ini PT. Daanish Mika Salsa telah melakukanpelayanan yang baik kepada jamaah yang melakukan ibadah umroh melalui PT.Daanish Mika Salsa dengan melakukan standar pelayanan sesuai dengan proseduryang telah ditetapkan, yaitu dimulai dari pendaftaran, pembayaran, manasik,keberangkatan, perjalanan ibadah, hingga kepulangan.

Nilai baik atau tidak pelayanan tidak hanya berdasarkan penilaian dari PT.Daanish Mika Salsa selaku travel penyelenggara tetapi juga berdasarkan jawabanyang diperoleh dari jamaah yang telah melakukan ibadah umroh melalui PT.Daanish Mika Salsa. Berdasarkan jawaban yang didapat, diperoleh hasil bahwaPT. Daanish Mika Salsa telah melakukan pelayanan yang baik dan berkualitaskepada jamaah, mulai dari 
pembimbing ibadah hingga hotel tempat menginap,semua sesuai denganprosedur pelayanan. Artinya, PT. Daanish Mika Salsa tidakhanya gencar melakukan kualitaspelayanannya kepada jamaah.

Di dalam merekrut jamaah, PT. Daanish Mika Salsa menggunakan lima strategiyaitu :

\section{Product (Produk)}

PT. Daanish Mika Salsa menawarkan produk-produk perjalanan ibadah umrohyang berkualitas.

\section{Place (Tempat)}

Saat akan mempersiapkan segala sesuatunya dalam bentuk pelayanan, PT.Daanish Mika Salsa selalu melengkapi fasilitas-fasilitas kantor dengan tujuanagar proses kinerja yang dilakukan oleh karyawan mampu memuaskan sertatamu atau pelanggan yang sedang berada didalam ruang lingkup PT. DaanishMika Salsa tidak merasa bosan dan nyaman.

\section{Price (Harga)}

Seperti yang telah dijelaskan sebelumnya, PT.Daanish Mika Salsa selalumenawarkan produk dengan harga yang bersaing.

\section{Promotion (Promosi)}

Dalam mempermudah agar masyarakat mudah untuk mengakses informasiyang dimiliki, PT. Daanish Mika Salsa memberikan sebuah informasi dalambentuk jejaring sosial. PT. Daanish Mika Salsa juga selalu mengikuti eventevent pameran yang biasanya diadakan di pusat-pusat perbelanjaan seperticontohnya Mall Bumi Kedaton.

5. Kerja sama dengan Travel sejenis

Strategi ini bukan hal yang baru bagi PT. Daanish Mika Salsa, pada tahapawal pembukaan, ada banyak biro perjalanan atau travel yang promosi, tetapi juga tetap memperhatikan

menawarkanbekerja sama. Biasanya, travel yang kehabisan kuota jamaah, akan mencaritravel lain yang bersedia memberangkatkan jamaah pada waktuwaktu yangdiinginkan oleh jamaah.

Berdasarkan hasil wawancara yang dilakukan, kelima marketing PT. DaanishMika Salsa sepakat mengatakan bahwa strategi yang paling efektif di dalampemasaran produknya adalah strategi promosi. Promosi akan dapat membantuPT.Daanish Mika Salsa untuk menyampaikan informasi-informasi yang ingindisampaikan kepada para konsumen dan calon konsumennya, jadi PT. DaanishMika Salsa tidak hanya bisa mendapatkan jamaah baru, tetapi juga jamaahberulang yang merupakan jamaah lama yang kembali lagi melakukan umrohmelalui PT. Daanish Mika Salsa.

Strategi promosi ini terbukti efektif, karena setelah PT. Daanish Mika Salsagencar melakukan promosi melalui media sosial dan pameran, jumlah jamaahselalu melebihi target yang telah ditetapkan. Strategi promosi mulai gencarditerapkan pada awal tahun 2016 hingga saat ini. Terbukti mulai dari tahun 2016,target yang ditetapkan adalah 1.000 jamaah, sedangkan realisasinya menjadi 1.008jamaah. Untuk tahun 2017, jumlah target yang ditetapkan masih sama sepertitahun sebelumnya, dan realisasinya adalah 1.117 jamaah. Di tahun 2019 nanti, PT.Daanish Mika Salsa menargetkan 1.500 jamaah dengan berbagai produkprodukbaru yang tentunya akan lebih bisa membuat jamaah merasa aman dan nyamandalam beribadah.

\section{KESIMPULAN DAN SARAN}

\section{Kesimpulan}


Berdasarkan hasil dan pembahasan yang telah dilakukan, maka kesimpulan yangdapat penulis ambil dalam penelitian ini yaitu :

a. Pelayanan yang dilakukan PT. DMS kepada jamaah, adalah PT. DMSmelakukan segala sesuatunya sesuai dengan prosedur yang telah ditetapkanoleh perusahaan guna meningkatkan pelayanan kepada jamaah, yang dimulaidari prosedur pendaftaran, prosedur pembayaran, prosedur manasik, prosedurkeberangkatan, prosedur perjalanan ibadah, serta prosedur kepulangan.

b. Strategi yang dilakukan oleh PT. DMS dalam meningkatkan kualitaspelayanan adalah dengan menggunakan strategi Product (Produk), Price (Harga), Place (Tempat), Promotion (Promosi), serta kerja sama dengan travellain yang sejenis. Strategi yang dilakukan oleh PT. DMS tidak semata untukmeraih keuntungan, tetapi juga sebagai sarana dalam peningkatan kulaitaspelayanan kepada jamaah.

c. Strategi yang paling efektif dilakukanoleh PT. DMS adalah strategi promosi,karena terbukti mampu menaikkan jumlah jamaah melebihi targetdibandingkan tahun-tahun sebelumnya. Pada tahun 2016, PT. DMS mulaigencar melakukan promosipromosi secara langsung melalui eventevent yangdiadakan di pusat perbelanjaan maupun melalui mediamedia sosial sehinggamampu merekrut 1008 orang jamaah, yang melampaui target dengan jumlah1000 orang jamaah. Pada tahun 2017, PT. DMS tetap menargetkan jumlahjamaah yang sama pada tahun 2016 yaitu sebanyak 1000 orang, danrealisasinya PT. DMS berhasil merekrut 1117 orang jamaah.
Saran

Saran yang ingin penulis sampaikan pada penelitian ini yaitu :

a. Diharapkan PT. DMS tetap senantiasa melaksanakan susunan strategi dalammeningkatkan kualitas pelayanannya pada program kegiatan PT. DMS.

b. Sebaiknya PT. DMS juga selalu melakukan controlling serta mengevaluasiprogram yang sedang dijalankan atau yang sudah berjalan. Dengan tujuan agarpelayanan perjalanan Umrah ke depannya lebih baik lagi.

c. Mempertahankan hubungan yang harmonis dan meningkatkan kualitas padakaryawan sehingga terciptanya kerjasama yang baik.

\section{DAFTAR PUSTAKA}

David, Fred R. 2012. Strategic Management (Manajemen Strategi Konsep) Edisi 12. Jakarta: Salemba Empat.

Dorothea, Wahyu. 2003. Manajemen Kualitas Pendekatan Sisi Kualitatif. Jakarta: Ghalia Indonesia.

Tjiptono, Fandy 2001. Prinsip-prinsip Pelayanan. Yogyakarta: Andi.

George R, Terry. 2014. Dasar-Dasar Manajemen. Jakarta: Bumi Aksara.

Kamilina, Rodhiyah, dkk. 2014. Penerapan Promotional Mix Pada Biro Perjalanan Umroh/Haji Shafira Tour and Travel Surabaya. Jurnal Ekonomi dan Bisnis. Surabaya: Univesitas Airlangga 
Kasmir. 2005. Etika Customer Service. Jakarta: PT.Raja Grafindo Persada.

Lamazio, M. Aziz. 2013. Strategi Promosi Jasa Perjalanan Haji dan Umroh Melalui Media Website. Jurnal Manajemen Dakwah. Semarang: , Univesitas Islam Negeri Walisongo.

Onang, Uchayana. 1992. Ilmu Komunikasi Teori dan Praktek. Bandung: PT. Rosda Karya.

Setiyawan, Hari Purwo. 2001. Manajemen Strategi. Lembaga Penerbitan. Jakarta: FEUI.

Suharsimi, Arikunto. 2010. Prosedur Penelitian: Suatu Pendekatan Praktik. Jakarta: PT. Rineka Cipta.

Nitisemito, Alex S. 2010. Manajemen Personalia: Manajemen Sumber Daya Manusia, Ed. 3. Jakarta: Ghalia Indonesia.

Sedarmayanti .2011. Sumber Daya Manusia dan Produktivitas Kerja. Bandung:Mandar Maju.

Syadam, Gauzali.2015. Manajemen Personalia Suatu Pendekatan Makro. Jakarta: Djambatan.

Veithzal Rivai \& Ahmad Fauzi .2015. Manajemen Sumber Daya Manusia. Jakarta: Raja Grafindo Persada. 